\title{
Level Up Intrinsic Motivation Using Gamification and Game-Based Learning
}

\section{Cynthia Cipriano Bullard}

Abstract: The purpose of this literature review is to compare and contrast gamification and game-based learning (GBL) and examine the benefits of using these strategies to encourage intrinsic motivation.

$\mathrm{n}$ order for intrinsic motivation to occur in the classroom, students need to feel a sense of connectedness to the task, feel they have the ability to master the task, and have the autonomy to direct their own learning (Ryan \& Deci, 2000). This literature review will focus on gamification and game-based learning (GBL) and the effect these strategies have on intrinsic motivation.

\section{Defining Gamification and Game- Based Learning}

The terms gamification and GBL are sometimes used interchangeably, but they are not the same. Game-based learning combines video games with educational concepts that allow students to apply their knowledge in an augmented reality (Cheng, Kuo, Lou \& Shih, 2012), while gamification is defined as a process: "using game thinking and game mechanics to solve problems or engage users." (Miller, 2012). When used in education, gamification provides a game-like learning environment where students have a more active learner role.

Educators may find the benefits of using gamification and GBL far outweigh the risk of moving away from traditional instructional methods when teaching today's students. This shift is supported because today's generation of students view technology as an all-pervasive necessity. According to adults surveyed in the U.S., today's students are twice as likely as previous generations to have played a video game in the past 24 hours (Pew Research Social \& Demographic Trends, 2010). Sixty-percent of U.S. children ages 8-18 played video games each day (The Henry J. Kaiser Family Foundation, 2010). This familiarity with the world of gaming makes the transition to using gamification and GBL in the classroom an easy one.

\section{Intrinsic Motivation}

Intrinsic motivation is defined as, "The doing of an activity for its inherent satisfactions rather than for some separable consequence." (Ryan \& Deci, 2000, pg. 56).

When surveyed about their ideal learning environment, 45 middle school students described a need for intrinsic motivation (Steinberg \& McCray, 2012). These students also cited the importance of student-directed learning and active learning environments, including hands-on and role-playing opportunities (Steinberg \& McCray, 2012).

Both gamification and GBL address students' desires for an active learning environment, one that also allows students to direct their own educational path (Steinberg \& McCray, 2012). Self-directed learning, or learning in which students are motivated to learn for the sake of learning, has been found to occur organically in GBL (Moon, Jahng, \& Kim, 2011). Further, the self-directed aspect of gamification and GBL allows students to take ownership of their education, an essential element of intrinsic motivation (Echeverri \& Sadler, 2011). 


\section{Intrinsic Motivation vs. Extrinsic Rewards}

Gamification includes reward systems, competition, and leveling up (Cheng, et al., 2012). A reward system requires students to complete tasks to navigate the game and move to higher levels. "The reward system in digital games is classified as one of the most important elements in game structure responsible for stimulating active and sustained game playing." (Moon et al. , 2011, pg. 3).

However, the use of a reward system has been both praised and criticized with regard to intrinsic motivation. While earlier studies determined extrinsic rewards detrimental to student motivation (Deci, 1971), more recent research contradicts this notion, finding reward systems were not innately detrimental to student learning (Cameron, Banko \& Pierce, 2001). Further, gamification has been shown to increase motivation when the experience is a dynamic one that provides opportunities for interaction between players and includes a challenge and reward system. This belief is echoed by students who found game elements such as leaderboards and other representations of their progress and achievements to be intrinsically motivating (Cheong, Cheong \& Filippou, 2013).

While educators strive to increase student engagement, there is a fine line between engaging students and meeting the expectations of high scores on end-of-the-year testing, especially when test scores are used to measure not only student growth but also teacher effectiveness. This pressure may cause teachers to be hesitant to shift from traditional to emerging educational methodologies (Barab, Sadler, Heiselt, Hickey \& Zuiker, 2007). This hesitation may persist, even when traditional learning environments are defined as stifling experiences based on rules, memorization, and recall of facts in isolation outside of a true context (Gee, 2003). When used in a classroom setting, gamification allows students to move from passive recipients of learning to active leadership roles as they collaborate with their peers, and assume responsibility for their own learning (Bullard, 2015). These types of experiences help foster intrinsic motivation. Students experience authentic learning when learning is participatory and meaningful, rather than traditional experiences that are limited to the acquisition of facts and memorization (Barab, Squire \& Dueber, 2000).

\section{Benefits of Gamification and GBL}

A gamified classroom fosters creative investigations that sustain learning over a long period and GBL provides learning environments where inquiry spurs creativity in both teacher and students (Frossard, Barajas \& Trifonoa, 2012). Students reap the benefits of this creativity as they move to the next level and take charge of their education. This type of learning environment not only enhances, but is also a catalyst for intrinsic motivation (Yien, Hung, Hwang \& Lin, 2011).

With the proliferation of social networking, both gamification and GBL speak to today's digitally immersed students, providing them the opportunity for shared learning and socialization, experiences which appeal to and engage learners (Simoes, Redondo \& Vilas, 2012). Branching out into social gamification provides both participatory and meaningful learning experiences.

\section{Conclusion and Future Study}

Although gamified learning environments have been shown to be intrinsically motivating, additional studies are needed to measure the correlation between gamified learning environments and academic success. Some research questions include the sustainability of a gamified classroom over the entirety of a school year, or whether there is a difference between implementing a gamified environment versus a $\mathrm{GBL}$ environment, or if the two are more successful when applied together. Longitudinal studies may not be necessary, but pre and post assessments to measure student growth, and to compare students who participated in 
gamified environments versus those who did not, may clearly define the effectiveness of gamification and GBL.

\section{References}

Barab, S. A., Sadler, T. D., Heiselt, C., Hickey, D., \& Zuiker, S. (2007). Relating narrative, inquiry, and inscriptions: Supporting consequential play. Journal of Science Education and Technology, 16(1), 59-82.

Barab, S. A., Squire, K. D., \& Dueber, W. (2000). A co-evolutionary model for supporting the emergence of authenticity. Educational Technology, Research and Development, 48(2), 37-62.

Bullard, C.C. (2015). Using gamification with middle school science students. In L. Schrum \& B.B. Levin (Eds.), Leading 21 st - century schools: Harnessing technology for engagement and achievement, second edition. Thousand Oaks: Corwin.

Cameron, J., Banko, K. M., \& Pierce, W. D. (2001). Pervasive negative effects of rewards on intrinsic motivation: The myth continues. The Behavior Analyst, 24(1) 1-44.

Cheng, Y., Kuo, S., Lou, S., \& Shih, R. (2012). The construction of an online competitive gamebased learning system for junior high school students. TOJET: The Turkish Online Journal of Educational Technology, 11(2), 214-227.

Cheong, C., Cheong, F., \& Fillippou, J. (2013). Using design science research to incorporate gamification into learning activities. PACIS 2013 Proceedings. Paper 156. http://aisel.aisnet.org/pacis2013/156

Deci, E. L. (1971). Effects of Externally Mediated Rewards on Intrinsic Motivation. Journal of Personality and Social Psychology, 18(1), 105-115.

Echeverri, J. F. \& Sadler, T.D. (2011). Gaming as a platform for the development of innovative problem-based learning opportunities. Science Educator, 20(1), 40-48.
Frossard, F., Barajas, M., \& Trifonova, A. (2012). A learner-centred game-design approach: Impact on teachers' creativity. Digital Education Review, 21, 13-22.

Gee, J. P. (2003). What video games have to teach us about learning and literacy. Gordonsville, VA, USA: Palgrave Macmillan. Retrieved November 23, 2014 from http://www.ebrary.com

Miller, A. (2012). Gamification vs. Game Based Learning in Education. Retrieved June 12, 2014 from

http://www.gamification.co/2012/01/13/gamifica tion-vs-game-based-learning-in-education/

Moon, M., Jahng, S., \& Kim, Y. (2011). A computer-assisted learning model based on the digital game exponential reward system. TOJET: The Turkish Online Journal of Educational Technology, 10(1), 1-14.

Ryan, R. M. \& Deci, E. L. (2000). Intrinsic and extrinsic motivations: Classic definitions and new directions. Contemporary Educational Psychology, 25, 54-67.

Simoes, J., Redondo, R., \& Vilas, A. (2013). A social gamification framework for a K-6 learning platform. Computers in Human Behavior, 29(2), 345-353. doi: 10.1016/j.chb.2012.06.007

Steinberg, M. \& McCray, E. (2012). Listening to their voices: middle schoolers' perspectives on life in middle school. The Qualitative Report, 17, $1-14$.

Yien, J., Hung, C., Hwang, G., \& Lin, Y. (2011). A game-based learning approach to improving students' learning achievements in a nutrition course. TOJET: The Turkish Online Journal of Educational Technology, 10(2), 1-10.

Millennials: Confident.Connected. Open to change. (2010, February 24). Pew Research Social and Demographic Trends. Retrieved on November 25, 2014 from http://www.pewsocialtrends.org/2010/02/24/mill ennials-confident-connected-open-to-change/ 
Generation M2: Media in the lives of 8 to 18year-olds. A Kaiser Family Foundation Study (2010, January 20). The Henry J. Kaiser Family Foundation. Retrieved on November 25, 2014 from http://kff.org/other/report/generation-m2media-in-the-lives-of-8-to-18-year-olds/

\section{About the Author}

Cynthia Cipriano Bullard, a 2014-15 Kenan

Fellow, is an award-winning educator with

14 years of teaching experience, is a NC Science Leadership Association Fellow, and the District

Five Director for the NC Science Teachers

Association. Other awards include the 2013

Distinguished Service in Science Education

Award, and the 2012 PRISM Award. 